\title{
The effect of seeding densities on old cultivated fields in Marakele National Park, Thabazimbi, South Africa
}

Piet J. van Staden ${ }^{1}$, George J. Bredenkamp ${ }^{1}$, Hugo Bezuidenhout ${ }^{2,3}$ and Leslie R. Brown ${ }^{3,}{ }^{*}$

\author{
${ }^{1}$ Department of Plant Sciences, University of Pretoria, Pretoria, South Africa \\ ${ }^{2}$ Scientific Services, SANParks, Kimberley, South Africa \\ ${ }^{3}$ Applied Behavioural Ecology and Ecosystem Research Unit, University of South Africa, Florida, South Africa
}

*Correspondence

Leslie R. Brown

Email: Irbrown@unisa.ac.za

\begin{abstract}
Large areas of the bushveld bioregion are converted from natural rangeland to cultivated fields for economic purposes. Conversion of grasslands to agricultural land alters the vegetation structure, plant species composition and ecological functioning. The aim of this paper was to evaluate the effectiveness of different seeding densities to enhance the restoration of old cultivated fields in Marakele National Park. Before these areas along the Motlhabatsi River were incorporated into the Park they were used for cultivation of crops. In an attempt to restore these areas to an improved condition, this pilot study was undertaken to determine best practice. One study area comprising two experimental sites and one control site were selected. A seed mixture consisting of natural grass species to the area was selected and sown at two different seed densities. The sites were monitored for a 2-year period for species diversity and composition. Data were analysed using the analysis of variance (ANOVA), while species diversity was calculated for the different experimental sites using the Shannon-Wiener index. Limited differences were observed between the two seeding densities. The results indicate that seeding degraded grasslands in these bushveld areas enhance the diversity and evenness of the degraded land.
\end{abstract}

\section{INTRODUCTION}

According to Low and Rebelo (1996), the conservation status of the South African savannah is good in principle, mainly due to the presence of the Kruger, Kgalagadi Transfrontier and Marakele National Parks (MNP) within the biome. Over decades, the land use in the savannah changed from cattle farming to game farming and it can, therefore, also be considered effectively preserved, provided that sustainable stocking levels were maintained. Numerous game farms that are located in the Savannah Biome of South Africa are characterized by secondary vegetation that developed on old fields, due to historical crop 
production activities. These areas are usually considered low production areas dominated by pioneer and/or subclimax plant species (Kritzinger \& Myburgh, 2008).

According to Mucina and Rutherford (2006), there was a substantial loss of savannah areas due to cultivation during the agricultural expansion period before the 1960s. Wessels, Reyers, Van Jaarsveld, and Rutherford (2003) identified potential conflict areas between land transformation and biodiversity conservation in the north-eastern part of South Africa. This transformation deals with the change from natural vegetation to other land uses, such as crop cultivation and urban development. The plains along the Motlhabatsi River were part of such a change from natural vegetation to crop cultivation, and some of these areas need to be transformed back to its former status, namely natural savannah. The eventual successful rehabilitation of such converted areas is an increasingly important conservation priority, which perhaps already became a necessity rather than an option because these areas are more suitable for game ranching or cattle farming than crop farming, because surface water is a limiting factor (Kritzinger \& Myburgh, 2008). However, Ehrenfeld (2000) stated that in many instances disturbed natural vegetation could be re-vegetated, but can never be completely restored to its former status. The implication of this re-vegetation may lead to a fair grazing potential, but with low species diversity (Ehrenfeld, 2000). Although the vegetation of such areas does recover from disturbance through succession, most aspects of community structure and species composition do not return without human intervention (Pywell et al., 2002; Van Oudtshoorn, Brown, \& Kellner, 2011).

Despite the frequent application of grassland restoration in conservation practice, little attention has been given to its usefulness in biodiversity conservation. Recent reviews on grassland restoration have focused on species transfer, establishment and restoration. According to Török, Vida, Deak, Lengyel, and Tóthmérész (2011) studies on grassland restoration of degraded areas, with a special emphasis on the applicability and costeffectiveness of the methods is warranted. Van Oudtshoorn et al. (2011) states that research on rehabilitation of old cultivated fields in South Africa is poorly documented, while limited information is available with regards to suitable seeding densities.

The MNP in the Limpopo Province of South Africa acquired a significant area of contractual land, (Marakele Pty. Ltd), to extend the existing area of the national park. It was estimated that between $9 \%$ and $10 \%$ of this extended portion consists of old cultivated fields and it was, therefore, envisaged that these areas should be rehabilitated to some state of resemblance of the vegetation that occurred there in historical times. This particular study was conducted on one of the above-mentioned old cultivated fields on the Marakele Pty. Ltd portion. The objective of this study was to investigate a seeding method to make recommendations for old cultivated land rehabilitation within Marakele Pty. Ltd. This paper aims to evaluate the effectiveness of different seeding densities to enhance the restoration of old cultivated fields in MNP. 


\section{MATERIALS AND METHODS}

\subsection{Study area}

The study area is located within the MNP and Marakele (Pty) Ltd which occurs on the plains north of the Waterberg Mountains in the Limpopo Province, South Africa. The plains landscape consists of midslopes, valley bottomlands, floodplains and rivers (Land Type Survey Staff 1988). The altitude ranges between 954 and 1,440 m above sea level (ASL) (Van Staden, 2015). The MNP and Marakele Park (Pty) Ltd is drained by the Motlhabatsi River system that is part of the Limpopo River system and forms the core of the drainage system of the MNP and Marakele Park (Pty) Ltd (Van Staden, 2002).

Marakele National Parks and Marakele (Pty) Ltd is situated approximately $13 \mathrm{~km}$ east from the town of Thabazimbi in the Waterberg District, Limpopo Province, South Africa (Figure 1). It extends from latitude $24.54081^{\circ}$ to $24.49407^{\circ} \mathrm{S}$ and longitude $027.44802^{\circ}$ to $027.76378^{\circ} \mathrm{E}$ (Van Staden, 2002). Mucina and Rutherford (2006) classified the vegetation of MNP and Marakele Park (Pty) Ltd as the Western Sandy Bushveld (SVcb16) and the Waterberg Mountain Bushveld (SVcb17) vegetation units in the Savannah Biome, the WaterbergMagaliesberg Summit Sourveld (SVcb17) vegetation unit in the Grassland Biome and the Marakele Afromontane Forest (SVcb17) in the Northern Afromontane Forest vegetation unit in the Afro-temperate, Subtropical and Azonal Forests Biome of South Africa. The latter occur in the Savannah and Grassland Biomes. The study area falls within the Western Sandy Bushveld (SVcb 16) in the Savannah Biome (Mucina \& Rutherford, 2006).
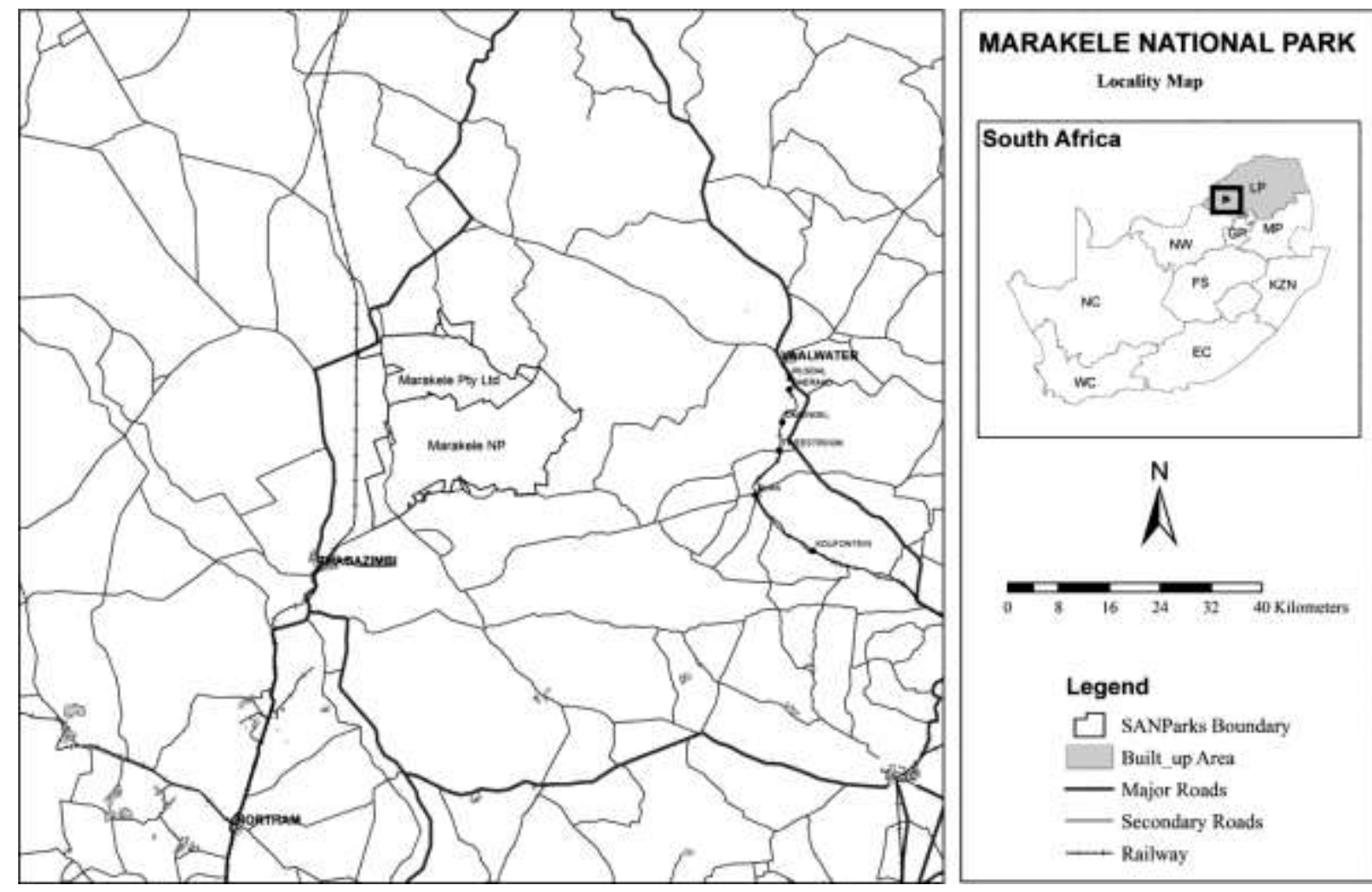

Figure 1 The location of the Marakele National Park and Marakele Park (Pty) Ltd (mapped by Google Maps) 
The MNP and Marakele Park (Pty) Ltd is underlain by various geological formations. The plains of the MNP and Marakele Park (Pty) Ltd consist shale and sandstone of the Langkloof Stage, Nylstroom Series and sandstone of the Sandriviersberg Formation of the Waterberg System (Van Staden, 2002, 2015). The western boundary of the MNP and Marakele (Pty) Ltd consists of black or red soils and calcrete of the Tertiary to Quaternary, underlain by volcanic rocks of the Archaean Complex (Van Staden, 2002, 2015).

The study area falls within terrain unit 4 of the $B d 42$ Land Type, with Avalon soil form as the dominant soil. The soil depth varies between 600 and 1,000 mm. The clay content in the Ahorizon varies between $12 \%$ and $22 \%$ and in the B-horizon between $15 \%$ and $25 \%$. The soil texture can be classified as a coarse sandy loam to a sandy clayey loam (Soil Classification Working Group 1991; Van Staden, 2015).

The rainfall, mainly during the spring and summer (September-March), can vary from as high as $1,196.9 \mathrm{~mm}$ per year to lower than $400 \mathrm{~mm}$ per year. The average annual rainfall for the MNP and Marakele Park (Pty) Ltd based on data collected in the MNP is just over $704.5 \mathrm{~mm}$ per annum (Van Staden, 2015). The temperature is less erratic than the rainfall with mild winter temperatures (coldest months June-July) as low as $-3.7^{\circ} \mathrm{C}$, while the summer temperatures (warmest months December to February) are as high as $40^{\circ} \mathrm{C}$. Frost occurs with the earliest date as 14 May and the latest date as 23 July, while the duration can be as long as 16 days (Land Type Survey Staff 1988). The experimental area is located on old field that was previously cultivated in the early 1990s. At this degraded grassland site, two different seeding density trials were initiated in the beginning of November 2002.

\subsection{Experimental design}

The study was conducted in the Albuca glauca-Senegalia mellifera shrubland plant community as described by Van Staden (2015). Three sites were selected namely a control site and two experimental sites. Two different seeding densities were used in this study namely 5 and $10 \mathrm{~kg} / \mathrm{ha}$. The total size of the study site was approximately 45 ha. No seeding was done in the control site. Grassland rehabilitation varies greatly regarding the seeding density. Many studies reported on seeding densities ranging between 5 and $45 \mathrm{~kg} / \mathrm{ha}$ (Mijnsbrugge, Bischoff, \& Smith, 2010; Pywell et al., 2002; Stevenson, Bullock, \& Ward, 1995; Török et al., 2011; Van Oudtshoorn, 2007). For this study, seeding densities of 5 and $10 \mathrm{~kg} / \mathrm{ha}$ were chosen as treatment due to cost and time constraints. The aim was to reintroduce various grass species natural to the area that should establish well under the prevailing climatic conditions.

The grass species composition of a seed mixture is strongly influenced by the aim of rehabilitation (e.g. target vegetation), the site conditions of receptor sites, or the availability of seed sources of potential target species (Török et al., 2011; Van Oudtshoorn et al., 2011). A mixture of natural grass species including pioneer, secondary successional and climax grasses natural to the area was used namely Digitaria eriantha, Panicum maximum, Cynodon dactylon, Anthephora pubescens, Cenchrus ciliaris, Heteropogon contortus, Bothriochloa insculpta, Cymbopogon pospischilii, Chloris virgata, Enneapogon cenchroides, Eragrostis echinochloidea, Eragrostis rigidior, Fingerhuthia africana, Pogonarthria squarrosa, Melinis repens and Urochloa brachyura. Sowing seed mixtures of target species is a widely 
used restoration method (Van Oudtshoorn et al., 2011). In both the experimental sites, the soil was slightly tilled to break the soil crust for better germination of seed and water penetration.

Three aspects were considered during the selection of the seed mixture namely the grass species composition of the A. glauca-S. mellifera shrubland, suitability of the habitat for a specific grass species and the availability of seed. For this study, natural grass seed was obtained from an ecological rehabilitation company, viz. EKO REHAB, Potchefstroom in the North-West Province. The seed mixture consisted of 16 different species (Table 1 ) which are mainly perennial late successional grass species. It was argued that the annual weeds already present in the plant community to a large extent full-filled the role of pioneer species (Van Oudtshoorn et al., 2011).

Table 1. Plant species density recorded for two growing seasons (SEM is the standard error of the mean; CV is the coefficient of variation in \%)

\begin{tabular}{|c|c|c|c|c|c|c|}
\hline Treatment & $\begin{array}{l}\text { Plant species density Means } \\
\quad\left(\text { ind } / \mathrm{m}^{2}\right) 02 / 03 \text { season }\end{array}$ & $\begin{array}{l}\text { Plant species density Means } \\
\left.\text { (ind } / \mathrm{m}^{2}\right) \text { 03/04 season }\end{array}$ & & & & \\
\hline Control & 20.8 & 25.5 & & & & \\
\hline $5 \mathrm{~kg} / \mathrm{ha}$ & 24.4 & 33.1 & & & & \\
\hline \multirow[t]{2}{*}{10 kg/ha } & 33.7 & 44.3 & & & & \\
\hline & Control & $5 \mathrm{~kg} / \mathrm{ha}$ & $10 \mathrm{~kg} / \mathrm{h}$ & Contro & $5 \mathrm{~kg} / \mathrm{h}$ & $10 \mathrm{~kg} / \mathrm{ha}$ \\
\hline SEM & 3.47 & 3.89 & 4.84 & 4.08 & 4.72 & 6.38 \\
\hline CV \% & 72.6 & 69.7 & 69.5 & 62.1 & 62.6 & 62.7 \\
\hline
\end{tabular}

The soil was prepared using the ripper method as described by Van Oudtshoorn (2007). A ripper was pulled behind a tractor to rip and break the crust and compaction of the topsoil. The seed was then sown by hand on both sides of the furrow made by the ripper. The seeds were sown during November 2002 before the rainy season started.

\subsection{Vegetation sampling}

A stratified random sampling method was used by taking samples uniformly in the control and seeding based vegetation structure. Ten sample sites of $200 \mathrm{~m}^{2}$ were placed in each of the experimental sites. A total of eight $1 \mathrm{~m}^{2}$ quadrants were placed four meters apart in each sample plot. Each quadrant was further divided into $0.25 \mathrm{~m}^{2}$ squares to assist with the counting of individual plants (Van Oudtshoorn, 2007). Plant species density data were recorded for two consecutive seasons, viz. 2002/03 and 2003/04. Sampling was conducted at the end of the growing season of each year, viz. March 2003 and March 2004, when plant species identification was optimal. All individual plant species within each $1 \times 1$ m quadrant were identified and their densities recorded. Due to the dominance of the grass species and as only grass species were used in this rehabilitation experiment, the analysis is therefore mainly focused on the grass species changes in diversity. As the study area is located in a 
National Park, no fences were erected around the sites resulting in wildlife being able to access the area.

\subsection{Data analysis}

The seeding data were subjected to analysis of variance (ANOVA) using the statistical program XLSTAT (AddingSoft 2014). The results were used to test for possible differences between the various seeding density treatments. Furthermore, multivariate data analysis, using ordination methods with the software XLSTAT (AddingSoft 2014) was employed to explore relationships between the different treatments in terms of species density within the seeding data set.

Species diversity was calculated for each of the different experimental sites for the two sample periods. Species diversity was calculated using the Simpson's index $(D)$ as well as the Shannon-Wiener index $\left(H^{\prime}\right)$ (Kent, 2012). Evenness was also determined for each community using Menhinick's index ( $\left.D_{\mathrm{b}}\right)$ (Menhinick, 1964).

\section{RESULTS AND DISCUSSION}

\subsection{Seedling emergence}

Seedling emergence in the $10 \mathrm{~kg} / \mathrm{ha}$ site was considerably higher $\left(640 \mathrm{ind} / \mathrm{m}^{2}\right)$ than in the control site (464 ind $/ \mathrm{m}^{2}$; Figure 3). The lowest seedling emergence was sampled in the control site (396 ind $/ \mathrm{m}^{2}$ ), where no soil disturbance or seeding was applied. From Figure 2, the dominance of the grasses in relation to the forbs can be clearly seen. The 2002/03 season total rainfall was lower than the long-term average rainfall of $521.9 \mathrm{~mm}$ for the same 4 months. Thus, a possible reason for the lower seedling establishment could be ascribed to the lower rainfall during that season. However, it could also be due to the grasses being established in the first year and able to increase their production in the following year. 


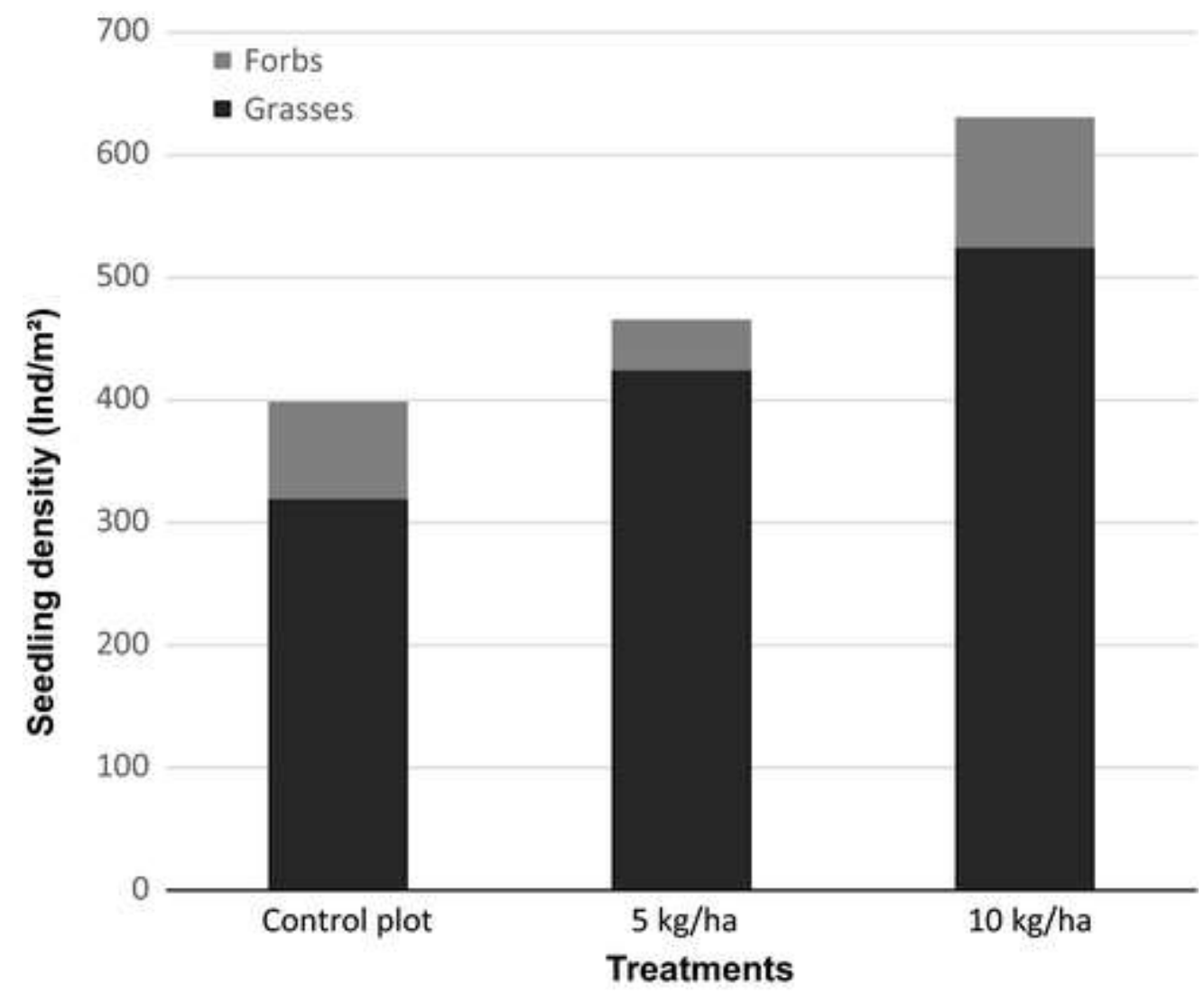

Figure 2 Seedling densities (ind $/ \mathrm{m}^{2}$ ) of grasses and forbs after establishment in the three sample sites (1 ha = control site)

The grass seedlings included pioneer grass species that were present in the soil seed bank, such as Aristida species, Urochloa mosambicensis as well as sown grass species such as Eragrostis chloromelas, D. eriantha and P. maximum.

The rainfall for the 4 months (December, January, February and March) after seeding was $166.0 ; 106.8 ; 14.0$ and $17.4 \mathrm{~mm}$ respectively, with a total of $304.2 \mathrm{~mm}$ for the 4 months in the 2002/03 season. In the following season (2003/04), the rainfall for these 4 months was $51.5 ; 225.5 ; 336.0$ and $289.6 \mathrm{~mm}$, respectively, totalling $902.6 \mathrm{~mm}$.

\subsection{Plant species density}

The plant species density data sets for the two recorded seasons (2002/03 and 2003/04) were analysed to explore the possible differences in the variability of the means between 5 and $10 \mathrm{~kg} / \mathrm{ha}$ and control sites. The data do not indicate significant differences between the mean values for the treatments (Table 1). The standard error of means (SEM) for the experimental sites ( 5 and $10 \mathrm{~kg} / \mathrm{ha}$ ) for the two seasons $(5 \mathrm{~kg} / \mathrm{ha} S E M=3.89$ and 4.72 and $10 \mathrm{~kg} / \mathrm{ha} S E M=4.84$ and 6.38 ) is more or less the same as the control (SEM = 3.47 and 4.08 ), indicating the low random variability per season between the means of the experimental and control sites (Table 1).

As with the standard error of the means (SEM - 5\% significance level), the highest variation was found among the experimental sites with lowest in the control site for the 2003/04 
season. The highest relative variation was obtained for the control site during the two growing seasons. The (CV) was $72.6 \%$ in $2002 / 03$ compared to $62.1 \%$ for the $2003 / 04$ season (Table 1 ).

According to the Shannon-Wiener index, the diversity in terms of grass species of the experimental sites was considerably higher than that of the control site over both seasons. The $5 \mathrm{~kg} / \mathrm{ha}$ site had a slightly higher diversity than the $10 \mathrm{~kg} / \mathrm{ha}$ site over both seasons (Figure 3). This was also reflected in the Simpson's index of diversity (not presented here). In addition, there was a larger evenness increase in the experimental sites over both seasons compared to the control site. The $5 \mathrm{~kg} / \mathrm{ha}$ site also had an insignificant but still better evenness than that of the $10 \mathrm{~kg} /$ ha site (Figure 4).

\subsection{0}

- 2002/03 - 2003/04

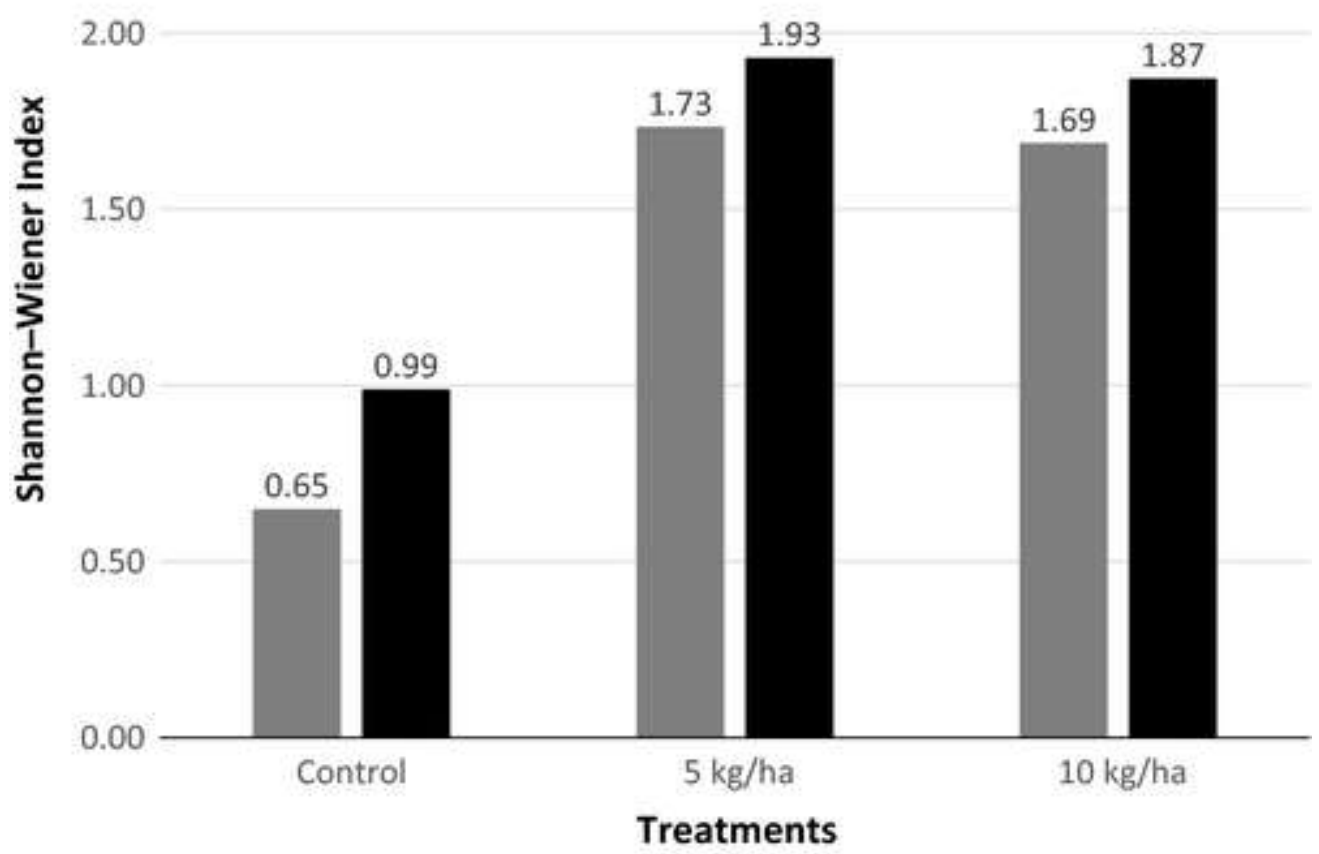

Figure 3 Shannon-Wiener index for the grass species of the experimental sites 


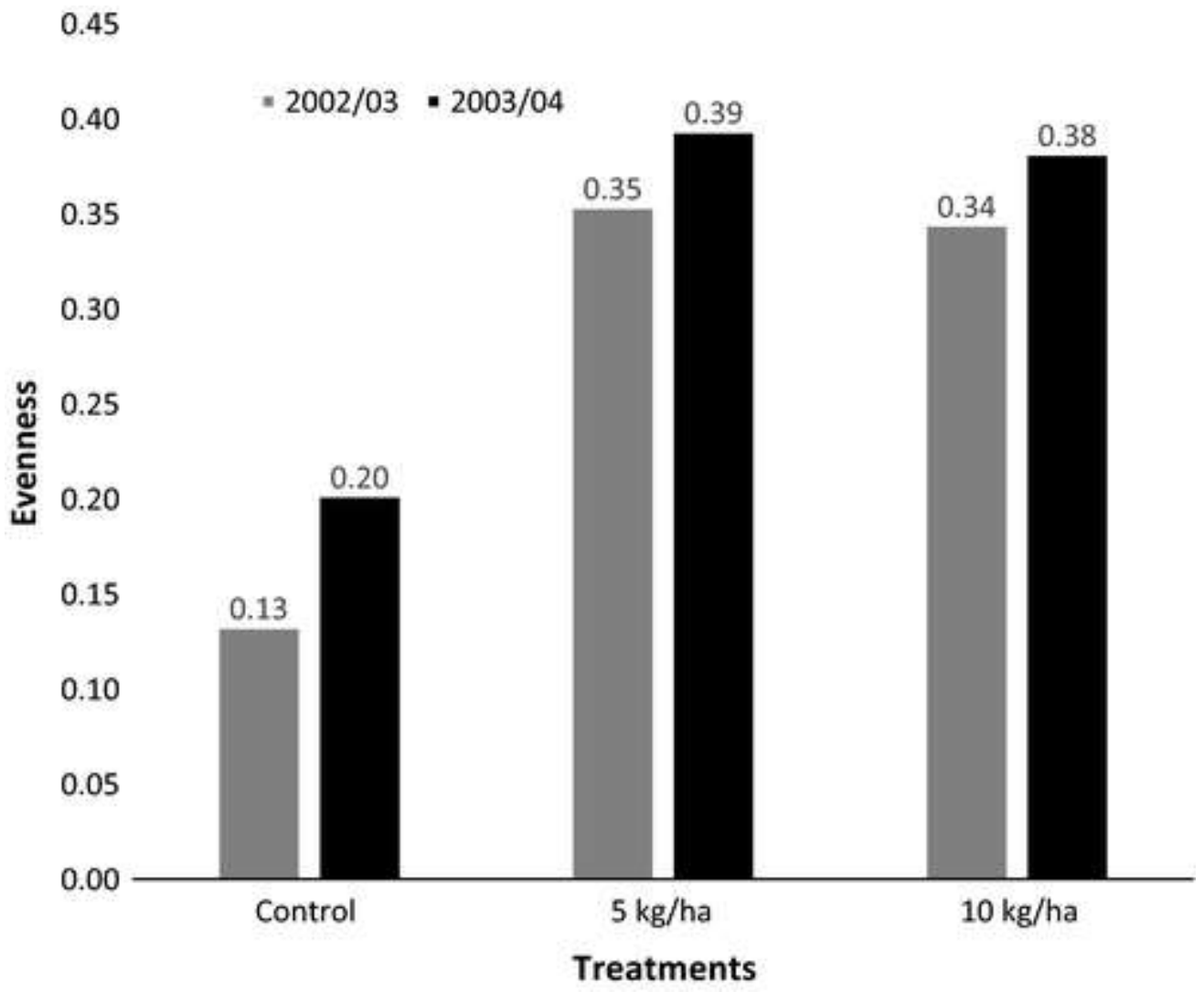

Figure 4 Differences in evenness between the different seasons

Substantial differences in plant densities were recorded between the control and the two experimental sites (Table 2). The experimental sites recorded a higher plant species density for both seasons than the control site. The difference in plant density can be ascribed to the apparent absence of a seedbed and the presence of a soil crust (preventing seed germination) in the control site.

Table 2. Plant densities of the control and experimental sites for two seasons (ind $/ \mathrm{m}^{2}$ )

\begin{tabular}{|c|c|c|c|}
\hline Site & $\begin{array}{l}\text { Plant density: season ind/sqm } \\
\qquad 2002 / 03\end{array}$ & $\begin{array}{l}\text { Plant density: season ind/sqm } \\
\qquad 2003 / 04\end{array}$ & $\begin{array}{c}\text { Difference between the two } \\
\text { seasons ind/sqm }\end{array}$ \\
\hline Control & 324 & 400 & 76 \\
\hline $5 \mathrm{~kg} / \mathrm{ha}$ & 411 & 544 & 133 \\
\hline $10 \mathrm{~kg} / \mathrm{ha}$ & 568 & 733 & 165 \\
\hline
\end{tabular}

Table 3 indicates that the treatment in the 5 and $10 \mathrm{~kg} / \mathrm{ha}$ sites differs considerably from the control site, but very little from each other. The highest correlation was found between the experimental sites, and even with the different seeding density, these two sites are positively correlated for the two seasons ( $r=.901 ; r=.934$; Table 3 ). 
Table 3. Correlation matrix for seeding densities and individuals per $\mathrm{m}^{2}$ for the control and experimental sites (2002/03-2003/04)

\begin{tabular}{|c|c|c|c|}
\hline $2002 / 03$ & Control & Ind/sqm (5 kg/ha) & Ind/sqm (10 kg/ha) \\
\hline Control & 1 & 0.487 & 0.594 \\
\hline $5 \mathrm{~kg} / \mathrm{ha}$ & 0.487 & 1 & 0.901 \\
\hline $10 \mathrm{~kg} / \mathrm{ha}$ & 0.594 & 0.901 & 1 \\
\hline $2003 / 04$ & Control & Ind/sqm (5 kg/ha) & Ind/sqm (10 kg/ha) \\
\hline Control & 1 & 0.525 & 0.616 \\
\hline $5 \mathrm{~kg} / \mathrm{ha}$ & 0.525 & 1 & 0.934 \\
\hline 10 kg/ha & 0.616 & 0.934 & 1 \\
\hline
\end{tabular}

In total, 29 plant species were recorded during the first and second season (control site not included). Plants recorded were mainly the sown species as well as annual weedy species such as Tagetes minuta and Bidens pilosa (Table 3).

The four most common plants recorded during both seasons were two sown grasses (C. virgata and $P$. maximum) as well as two nonintroduced grasses (U. mosambicensis and Eragrostis lehmanniana). Three sown grass species were not found in the control site or in the two experimental sites ( 5 and $10 \mathrm{~kg} / \mathrm{ha}$ ), viz. A. pubescens, $F$. africana and $U$. brachyura. This could most likely be ascribed to the degraded habitat not being suitable for these species (Fish, Mashau, Moeaha, \& Nembudani, 2015). Five nonsown grass species as well as 11 forb species were recorded for both seasons in the control and ripped sites (Table 4). The sown species with the lowest presence was $C$. pospischilii.

Table 4. Density (ind $/ \mathrm{m}^{2}$ ) of species recorded during both seasons as well as a difference in density between the two seasons

\begin{tabular}{|c|c|c|c|c|}
\hline Species & Abbreviation & $\begin{array}{l}\text { Season } 2002 / 03 \\
\quad \text { (ind } / \mathrm{m}^{2} \text { ) }\end{array}$ & $\begin{array}{l}\text { Season } 2003 / 04 \\
\quad \text { (ind } / \mathrm{m}^{2} \text { ) }\end{array}$ & $\begin{array}{l}\text { Difference in density between the } \\
\text { two seasons }\end{array}$ \\
\hline Urochloa mosambicensis & Uro mos & 180 & 234 & 54 \\
\hline Chloris virgata (S) & Chl vir & 149 & 162 & 13 \\
\hline Eragrostis lehmanniana & Eraleh & 119 & 145 & 26 \\
\hline $\begin{array}{l}\text { Eragrostis } \\
\text { echinochloidea (S) }\end{array}$ & Era ech & 49 & 60 & 11 \\
\hline Aristida congesta & Aricon & 87 & 103 & 16 \\
\hline Datura stramonium (F) & Dat str & 32 & 32 & 0 \\
\hline Melinis repens (S) & Mel rep & 89 & 120 & 31 \\
\hline Tragus berteronianus & Tra ber & 59 & 69 & 10 \\
\hline
\end{tabular}




\begin{tabular}{|c|c|c|c|c|}
\hline Species & Abbreviation & $\begin{array}{l}\text { Season } 2002 / 03 \\
\text { (ind } / \mathrm{m}^{2} \text { ) }\end{array}$ & $\begin{array}{l}\text { Season } 2003 / 04 \\
\quad \text { (ind } / \mathrm{m}^{2} \text { ) }\end{array}$ & $\begin{array}{l}\text { Difference in density between the } \\
\text { two seasons }\end{array}$ \\
\hline Eragrostis rigidior (S) & Era rig & 74 & 120 & 46 \\
\hline $\begin{array}{l}\text { Enneapogon cenchroides } \\
\text { (S) }\end{array}$ & Enn cen & 31 & 54 & 23 \\
\hline Tagetes minuta (F) & Tag min & 48 & 56 & 8 \\
\hline $\begin{array}{l}\text { Heteropogon contortus } \\
\text { (S) }\end{array}$ & Het con & 97 & 135 & 38 \\
\hline Amaranthus hybridus (F) & Ama hyb & 25 & 26 & 1 \\
\hline Cynodon dactylon (S) & Cyn dac & 65 & 84 & 19 \\
\hline Indigofera filipes (F) & Ind fil & 48 & 63 & 15 \\
\hline Panicum maximum (S) & Pan max & 152 & 207 & 55 \\
\hline Schkuhria pinnata (F) & Sch pin & 21 & 24 & 3 \\
\hline $\begin{array}{l}\text { Gomphrena celosioides } \\
\text { (F) }\end{array}$ & Gom cel & 15 & 13 & -2 \\
\hline Hibiscus trionum (F) & Hib tri & 44 & 102 & 58 \\
\hline $\begin{array}{l}\text { Pogonarthria squarrosa } \\
\text { (S) }\end{array}$ & Pog squ & 38 & 42 & 4 \\
\hline Felicia muricata (F) & Fel mur & 17 & 20 & 3 \\
\hline $\begin{array}{l}\text { Helichrysum caespititium } \\
\text { (F) }\end{array}$ & Helicae & 15 & 15 & 0 \\
\hline Bidens pilosa (F) & Bid pil & 11 & 12 & 1 \\
\hline $\begin{array}{l}\text { Bothriochloa insculpta } \\
\text { (S) }\end{array}$ & Bot ins & 13 & 11 & -2 \\
\hline Conyza bonariensis (F) & Con bon & 10 & 12 & 2 \\
\hline Digitaria eriantha (S) & Dig eri & 96 & 114 & 18 \\
\hline Hyparrhenia hirta & Hyp hir & 7 & 10 & 3 \\
\hline $\begin{array}{l}\text { Cenchrus ciliaris } \\
\text { (Molopo) (S) }\end{array}$ & Cen cil & 56 & 70 & 14 \\
\hline $\begin{array}{l}\text { Cymbopogon pospischilii } \\
\text { (S) }\end{array}$ & Cym plu & 5 & 6 & 1 \\
\hline Total number of ind $/ \mathrm{m}^{2}$ & & 1,652 & 2,121 & 469 \\
\hline
\end{tabular}

Sown species are indicated with an "S," and a minus (-) symbol in the far-right column indicates a decrease in the species density. Forbs are indicated with an " $\mathrm{F}$ ". 
The total average number of plants increased slightly from 1,652 to $2,121 \mathrm{ind} / \mathrm{m}^{2}$, from $2002 / 03$ to $2003 / 04$. The main reason for the increase could be that the rainfall increased from 2002/03 season to the 2003/04 season (Table 4). Only two plant species decreased from the first season to the second season, viz. the weedy forb Gomphrena celosioides and a sown grass $B$. insculpta. Both these species occur abundantly in degraded areas. Their decline could be the result of the secondary successional-climax grass species becoming more established.

\subsection{Ordination 2002/03 season}

The ordination diagram indicates a strong correlation between the two experimental sites that differ considerable from the control site viz. U. mosambicensis (a nonsown species associated with the control site) and $C$. virgata, $P$. maximum and $D$. eriantha (sown species associated with the experimental sites). The two experimental sites are the closet to the centroid, indicating their positive correlation with the sown species as well as nonsown species that were recorded in these sites during the first season (Figure 5).

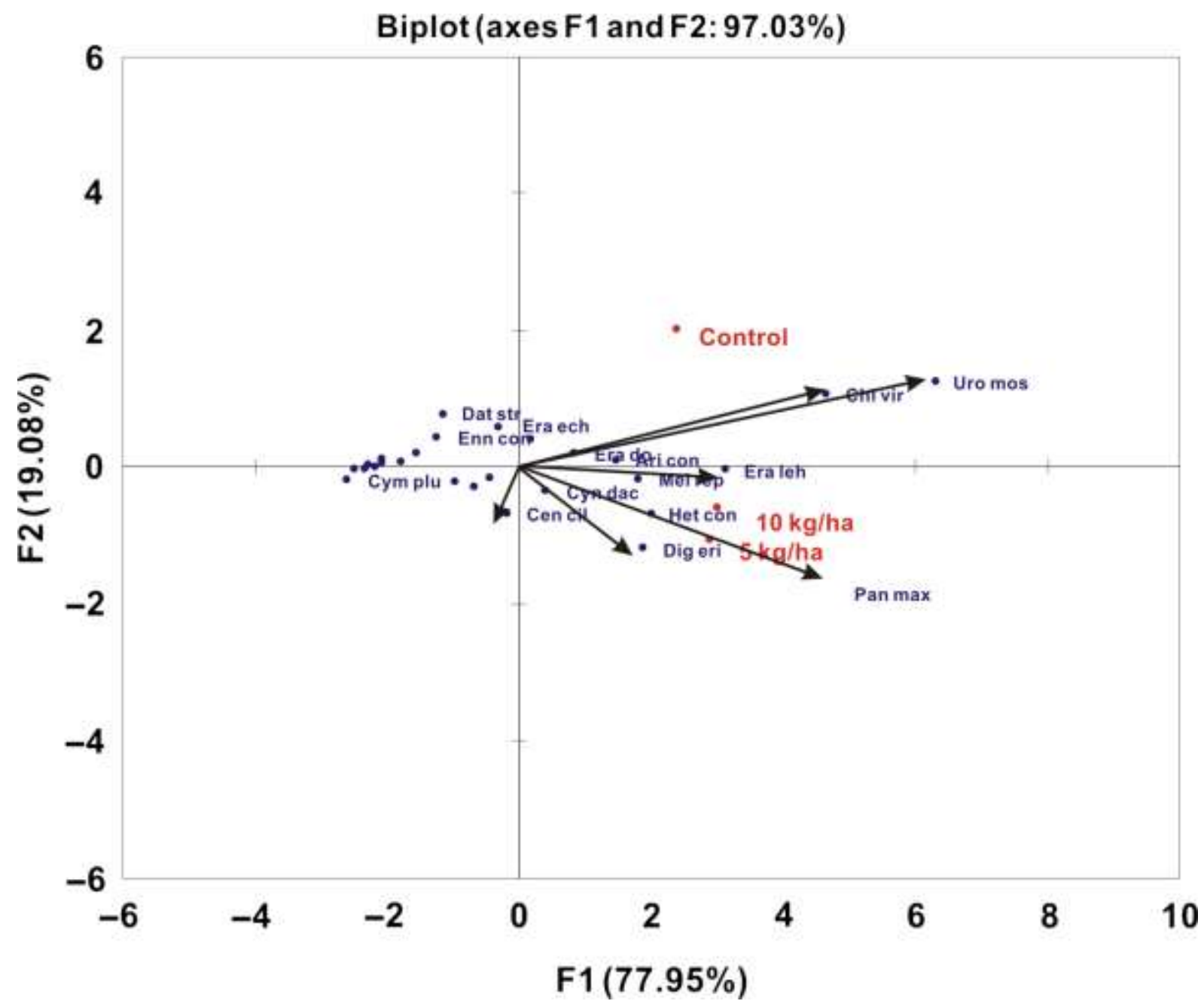

Figure 5 Principal component analysis ordination biplot showing correlations between the two different seeding densities and species scores during the first recorded season (2002/03). See Table 4 for species abbreviations 
Species found in the control site consisted of nonsown species as well as sown species (seed that occurred in the soil). As these species are associated with and close to the centroid, it indicates their correlation towards both seeding rate treatments (Figure 5).

Both experimental sites are situated on more or less the same line and direction showing the little influence seeding density had on the species density. It is also clear from the biplot that the sown and nonsown species are strongly related between the control site and the two experimental sites (Figure 5).

\subsection{Ordination 2003/04 season}

During the second season, the correspondence analyses show a slightly stronger positive correlation, viz. $r=.934$ between the two sites where the two different seeding densities were applied than during the first recorded season, viz. $r=.901$. The control site is less strongly correlated with the two seeding density variables for the 2003/04 season, but slightly stronger related than the 2002/03 season (Figure 6). Nearest to the centroid were the two seeding densities, indicating their positive correlation with the sown species as well as nonsown species.

\section{Biplot (axes F1 and F2: $98.03 \%$ )}

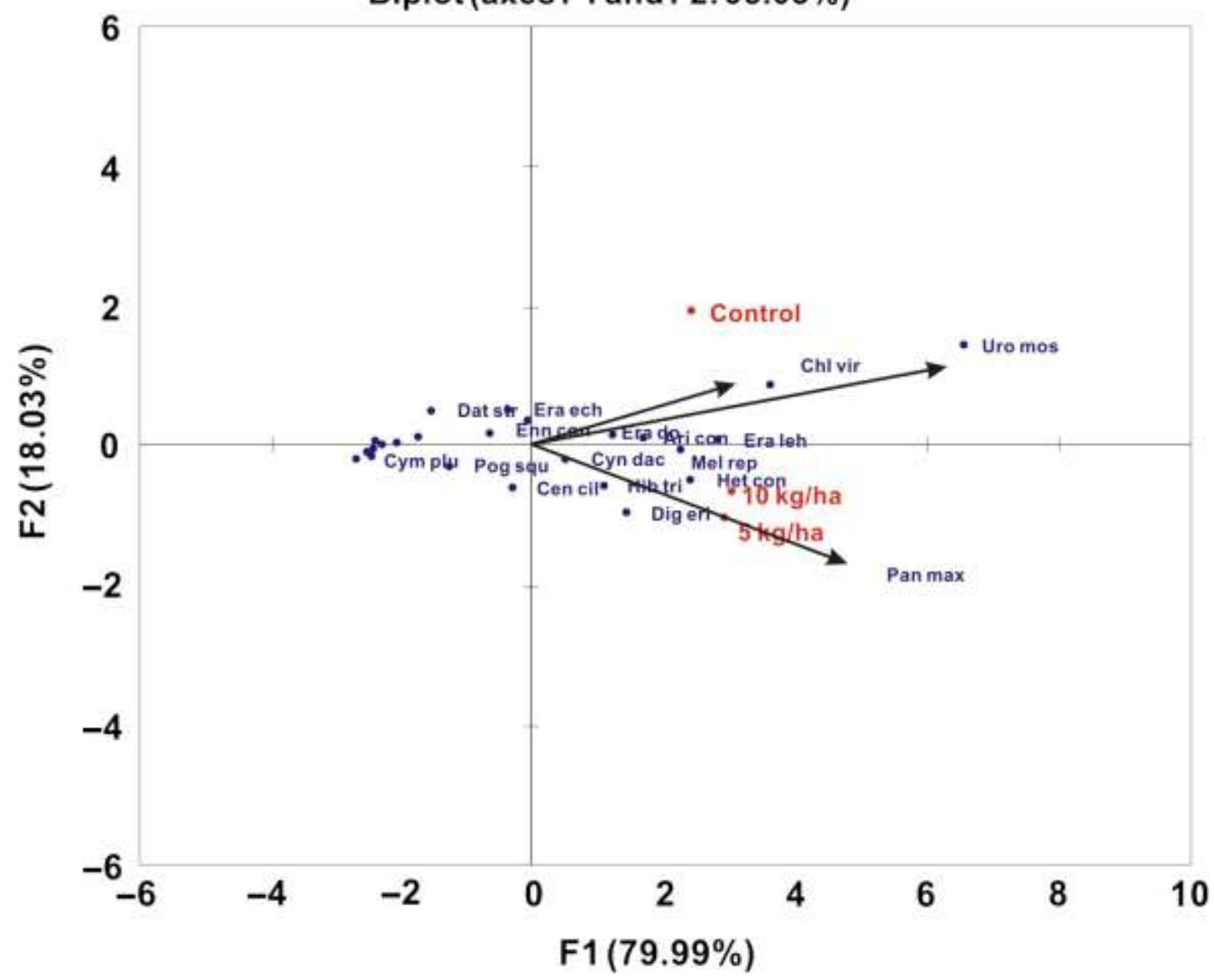

Figure 6 Principal component analysis ordination biplot showing correlations between the two different seeding densities and species scores during the second recorded season (2003/04). See Table 3 for species abbreviations 
Only the nonsown species $U$. mosambicensis and sown species $C$. virgata and $P$. maximum are located away from the centroid, whereas all the other species recorded are clustered near the centroid (Figure 6).

\subsection{Canonical correlation analysis between the 2002/03 and 2003/04 seasons}

There is a strong correlation between the two experimental sites $(r=.901)$ in the first season $(r=.901)$ and in the second season $(r=.934)$.

\section{CONCLUSION}

According to Van Oudtshoorn (2007), the re-establishment of plant species and the reconstitution of seed banks are crucial in promoting biodiversity on degraded areas. The aim of this study was to evaluate the effectiveness of different grass seeding densities on old cultivated fields of the MNP. No similar research has been conducted in the region before. The grass mixture used consisted of a combination of climax, secondary successional and pioneer species that naturally occur in the area. The results of this baseline study are encouraging and indicate that seeding of grass species increased the biodiversity of the old cultivated fields significantly. This has also been found by Van Oudtshoorn (2007) in the Highveld grassland area of South Africa. Not only was an increase in diversity with respect to grass species observed, but also the evenness of the two experimental sites increased considerably. The control site also showed a slight increase in biodiversity, though it consisted mainly of pioneer weedy species.

In terms of seeding density, the two experimental sites had a high correlation with respect to species densities indicating that the higher seeding rate had little effect on the establishment of a denser herbaceous layer. To the contrary, the lower seeding density ( $5 \mathrm{~kg} / \mathrm{ha}$ ) had a slightly higher species diversity after two seasons. From a costing perspective, this provides valuable information for the land manager especially on privately owned game farms.

The sown grass species $C$. virgata, $E$. rigidior, $M$. repens, $H$. contortus, $P$. maximum and $D$. eriantha had the highest density for both seasons. The following nonsown grass species had the highest densities for both seasons: U. mosambicensis, E. lehmanniana, Aristida congesta subsp. congesta, Tragus berteronianus and E. cenchroides. The grass species recorded in the experimental sites were mostly grasses that commonly occur in the natural surrounding grassland, and the sowing of natural grass seeds did not change the grass species composition, but aided in the recovering of the degraded old cultivated fields to a secondary successional stage. The fact that the experimental sites were not protected against the utilization from wildlife could have had an effect on the density of the grass cover as well, because the herbaceous layer was frequently grazed by wildlife.

The results of this study indicate that seeding of natural grass species enhances plant species diversity and thus contributes to restoration in the bushveld bioregion. Although the system was not completely rehabilitated to its original condition Ehrenfeld (2000), the reseeding has had a major effect on secondary plant succession with an increase in vegetation cover and species diversity. The main reason for this is the re-seeding of the various mid- 
late successional and climax grass species that were absent in the soil of cultivated fields (Van Oudtshoorn et al., 2011). If seeds of these grasses are not commercially available, it could be harvested from the natural grasslands within the same plant communities closest to the rehabilitation site.

It is commonly known that cultivation activities transform the physical and chemical properties of the soil. This has a negative effect on the rate of succession and the species composition of such an area (Van Oudtshoorn et al., 2011). Although not part of this study, it is recommended that the soil nutrient status of the rehabilitated and control areas is also studied to provide more insight into the effect of re-seeding on the soil. Lastly, it is recommended that the study site is monitored on a long-term basis to determine further species compositional changes to assist our understanding of the ecological processes of these old fields.

\section{REFERENCES}

Addingsoft (2014). XLSTAT. Version 4.06.

Ehrenfeld, J. G. (2000). Defining the limits of restoration: The need for realistic goals. Restoration Ecology, 8, 2-9.

Fish, L., Mashau, A. C., Moeaha, M. J., \& Nembudani, M. T. (2015). Identification guide to southern African grasses. An identification manual with keys, descriptions and distributions. Strelizia 36. Pretoria: South African National Biodiversity Institute.

Kent, M. (2012). Vegetation description and data analysis: A practical approach. London: Belhaven Press.

Kritzinger, J. H., \& Myburgh, W. J. (2008). Secondary (Old Land) succession in the Sourish Mixed Bushveld, Limpopo Province. In Land Transformation and Rehabilitation. 43rd Annual Congress of the Grassland Society of Southern Africa Land Type Survey Staff (1988). Land types of the maps 2426 Thabazimbi, 2428 Nylstroom. Memoirs on the Agricultural Natural Resources of South Africa, 10, 1-431.

Low, A. B., \& Rebelo, A. G. (Eds.) (1996). Vegetation of South Africa, Lesotho and Swaziland. Pretoria: Department of Environment Affairs and Tourism.

Menhinick, E. F. (1964). A comparison of some species-individuals diversity indices applied to samples of field insects. Ecology, 45, 859-861.

Mijnsbrugge, K., Bischoff, A., \& Smith, B. (2010). A question of origin: Where and how to collect seed for ecological restoration. Basic and Applied Ecology, 11, 300-311.

Mucina, L., \& Rutherford, M. C., eds (2006). The vegetation of South Africa, Lesotho and Swaziland. Sterlitzia 19. Pretoria: South African Biodiversity Institute. 
Pywell, R. F., Bullock, J. M., Hopkins, A., Walker, K. J., Sparks, T. H., Burkes, M. J. W., \& Peel, S. (2002). Restoration of species-rich grassland on arable land: Assessing the limiting processes using a multi-site experiment. Journal of Applied Ecology, 76, 1116-1133.

Soil Classification Working Group (1991). Soil classification: A taxonomic system for South Africa. Memoirs on the Agricultural Natural Resources of South Africa, 15, 1-262.

Stevenson, M. J., Bullock, J. M., \& Ward, L. K. (1995). Recreating seminatural communities, effects of sowing rate on establishment of calcareous grasslands. Restoration Ecology, 3 , 279-289.

Török, P., Vida, E., Deak, B., Lengyel, S., \& Töthmérész, B. (2011). Grassland restoration on former croplands in Europe: An assessment of applicability of techniques and costs.

Biodiversity and Conservation, 20 (11), 2311-2332.

Van Oudtshoorn, F. P. (2007). The evaluation of various reseeding methods for restoring old croplands in the Highveld Region of South Africa. M.Tech. Thesis, University of South Africa.

Van Oudtshoorn, F. P., Brown, L. R., \& Kellner, K. (2011). The effect of reseeding methods on secondary succession during cropland restoration in the Highveld region of South Africa. African Journal of Range \& Forage Science, 28(1), 1-8.

Van Staden, P. J. (2002). An ecological study of the plant communities of the Marakele National Park. M.Sc Thesis, University of Pretoria, Pretoria.

Van Staden, P. J. (2015). Aspects of the vegetation ecology of the Marakele National Park and Marakele Park (Pty) Ltd, Limpopo Province, South Africa. PhD thesis, University of Pretoria, Pretoria, South Africa.

Wessels, K. J., Reyers, B., Van Jaarsveld, A. S., \& Rutherford, M. C. (2003). Identification of potential conflict areas between land transformation and biodiversity conservation in northeastern South Africa. Agriculture, Ecosystems \& Environment, 95, 157-178. 